\title{
The Departure from the Linear Text
}

\begin{abstract}
AвSTRACT: For millennia, ever since the advent of writing, the mediation of complex knowledge has been restricted to the written transfer of information through linear text. Academic communication primarily uses linear text, even for mathematical and scientific matters. For around 20 years, the progressive digitisation of academia has enabled the visualisation of complex contexts and their propagation on a massive scale without being bound to linear text. The externalisation of knowledge and its transfer from one person to another can now also take place with the aid of alternative techniques. This is virtually tantamount to a revolution in academic communication. Particularly for libraries, however, this poses an enormous challenge as, for the last 2,000 years, they have been geared towards storing and disseminating academic results almost exclusively as textual forms.
\end{abstract}

KEYwORDS: Academic Communication, Text, Non-linearity, Digitization, Visualization, Knowledge Transfer, Digital Text

\section{Introduction}

The he term academic communication carries two different connotations: on the one hand, the mediation of academic content to an interested general public (academic mediation, transmission to the mainstream); on the other hand, academic communication (also scholarly communi- 
cation) means the conveyance of academic content within an academic community. In the following, we intend to addresssolelythe latter.

Around two decades ago, the parameters for academic communication changed dramatically. The most important change was digitisation. The shift from printed media to the digital, electronic format revolutionised the field. Here, the number of academic journals was vast, particularly in what is known as the STM sector. The steady increase of the price of journals triggered the so-called „serial crisis” in the mid-1990s. Many libraries were no longer able to continue their subscriptions and had to cancel journals on a large scale. Consequently, several initiatives were launched that called for - and still do to this day - free access to academic information (e.g. the Budapest Open Access Initiative 2002, the Berlin Declaration on Open Access 2003 and the Bethesda Statement on Open Access 2003) ${ }^{1}$.

The main prerequisite for all these changes and demands is the digital availability and propagation of academic content. Especially in the STM sector, the number of electronic journals (eventually, also the number of iBooks) has virtually skyrocketed ${ }^{2}$.

The first electronic journals, however, were still a true reflection of their printed predecessors. In the great majority of cases, fundamental functions such as searchable text or links within the publication by way of hypertext were not even provided ${ }^{3}$. Hence, the actual added value of the digital format was scarcely implemented. After all, as long as the electronic version of a journal or book constitutes merely an analogue copy of the print version, the drawbacks of the electronic medium outweigh the advantages.

Before too long, however, authors, editors and producers of electronic academic information capitalised on the fundamental innovations and

${ }^{1}$ Budapest-Vienna Declaration on the European Higher Education Area [online]. 2010 [access 10 October 2017]. Available in Internet: http://www.ehea.info/media.ehea.info/ file/2010_Budapest_Vienna/64/0/Budapest-Vienna_Declaration_598640.pdf; Realising the European Higher Education Area [online]. 2003 [access 10 October 2017]. Available in Internet: http://www.eees.es/pdf/Berlin_EN.pdf.

2 S. Hitchcock, L. Carr, W. Hall. A Survey of STM Online Journals 1990-1995: The calm before the Storm. In: The Open Journal Project [online]. 15 January 1996 [access 10 October 2017]. Available in Internet: http://journals.ecs.soton.ac.uk/survey/survey.html.

3 Ibid. 
assets of electronic publishing and the purely electronic text was supplemented with a wide variety of additional digital materials.

An original academic paper or book was thus transformed into a multimedia product. Although the linear reading of the text did not exactly take a backseat, it was supplemented by new forms of perception ${ }^{4}$.

Nonetheless, the majority of scientists continue to rely on the familiar exchange of knowledge predominantly through academic print journals and books, which has been successful for centuries. Here, a text is read in a linear manner, i.e. from left to right and from top to bottom. Even if we skim-read texts online, we still follow this reading pattern. In the age of the hypertext, however, this is not the most efficient method to consume academic texts. This especially goes for subject areas that focus heavily on visual information or large quantities of research data, such as medicine or astrophysics, where the linear text no longer caters to their needs; it is far too slow, static and non-interactive. New forms of propagation and presentation allow the available technological possibilities of networking and collaboration to be exploited.

These days, for example, so-called data journals exist, in which texts are no longer printed, but rather only sets of academic data are provided and, if need be, commented upon ${ }^{5}$. Video journals are also a new development on the academic communication market. Academic insights are either used exclusively through moving image materials (videos) or as a substantial supplement to the research results prepared in writing ${ }^{6}$. This carries major advantages in medical journals, such as in the communication of operating procedures, for example. Meanwhile, so-called „video abstracts" as used in Elsevier publication, for instance, can be described

${ }^{4}$ Budapest-Vienna Declaration, op. cit.

${ }^{5}$ See H. V. Nguyen, et al., Preference and willingness to pay for nutritional counseling services in urban Hanoi [version 1; referees: 2 approved, 1 approved with reservations]. „F1000Research” [online] 2017, 6:223 [access 10 October 2017]. Available in Internet: https://f1000research.com/articles/6-223/v1.

6 See S. Spicer, Exploring Video Abstracts in Science Journals: An Overview and Case Study. "Journal of Librarianship and Scholarly Communication” [online]. 2014, 2 (2) [access 10 October 2017]. Available in Internet: http://jlsc-pub.org/articles/abstract/10.7710/2162-3309.1110/; ,Journal of Advances in Neurosurgery” [online] 2012[access 10 October 2017]. Available in Internet: http://www.vjadvancesinneurosurgery. com/index.php. 
as commonplace ${ }^{7}$. There are also examples of journals that specialise in the visualisation of experiments, whereby textual statements are kept to a minimum, such as „Journal of Visualized Experiments” (JoVE) ${ }^{8}$.

\section{A slice of history}

The first evidence of (seemingly academic) descriptions are found in Palaeolithic cave paintings, which were used as a timeless means of communication long before the written word, such as in the Lascaux Cave9

Only after the development of writing did the linear understanding of texts makes its debut. We experienced the first paradigm shift in academic communication 2,000 years ago. Up to that point, it was a strict rule of academic communication and (for the most part philosophical) discussions to conduct purely oral disputations in the academic cognitive process. The philosophical schools were the seeds of today's universities and academic institutions. One of the greatest proponents of oral communication was Plato, who fought vehemently against written records of his subject matter and harboured a general scepticism of the purposefulness of written discourse ${ }^{10}$. It was Aristotle who expedited the paradigm shift at the time. For him, written records were imperative to be able to transport unequivocal subject matter unchanged and independently of time and space, and supply large groups of people with the same subject matter. History has shown that Aristotle and the dictum of the written word have survived, at least in the main, until the present day ${ }^{11}$.

7 See Y. Li, S. C. Benjamin, High threshold distributed quantum computing with three-qubit nodes. „New Journal of Physics” [online] 2012, vol. 14 [access 10 October 2017]. Available in Internet: http://iopscience.iop.org/article/10.1088/1367-2630/14/9/093008 or Video Abstact [online] [10 October 2017]. Available in Internet: https://www.journals. elsevier.com/journal-of-number-theory/video-abstracts.

${ }^{8}$ „Journal of Visualized Experiments" [online]. [access 10 October 2017]. Available from:https://www.jove.com/.

9 Lascaux In: Wikipedia [online] [access 10 October 2017]. Available in Internet: https://en.wikipedia.org/wiki/Lascaux.

10 See Plato, Phaidros 274b-278b; Seventh Letter 340b-345c; T. A. Szlezák. Reading Plato, London, New York 1999, pp. 56-71.

11 M. Cahn, Die Medien des Wissens. Sprache, Schrift und Druck, [in:] Der Druck des Wissens. Geschichte und Medium der wissenschaftlichen Publikation, ed. Michael Cahn, 
The propagation of religious, political and academic content during the Renaissance can also be regarded as proof of the success of the written word. The invention of the printing press by Gutenberg in 1454 clearly cemented the primacy of the written word. Virtually unchallenged until the 1800 s, this dictum proved strong and helpful, which is also evident in the surge in academic publications (especially in journals) towards the middle and end of the $19^{\text {th }}$ century.

The success story of the academic journal only began in 1669 with the first of its kind, „Le Journal des Sçavans”. The emerging natural sciences had necessitated new forms of academic communication. Thick, extensive books were unsuitable for conveying (academic) research results. A small format was called for that could reach the respective academic community swiftly, currently, at short notice and extremely frequently, and was available for an exchange of ideas. The emergence of a professional publishing industry as part of the propagation and communication of academic content was part and parcel of the development of academic communication in the $17^{\text {th }}$ century.

For centuries, academic works were published almost exclusively in print form and therefore a linear manner. The aforementioned academic journals and their specialist articles played a key role here. A significant number of these papers had - and still have - an influence that lasted several decades or far longer. The first two academic peer-reviewed journals published their first issues almost simultaneously in 1665: „Le Journal des Sçavans” (dated 5 January 1665) and „The Philosophical Transactions of the Royal Society" (6 March 1665) ${ }^{12}$.

Additional design tools such as images, diagrams and tables were soon added to pure text. In the mid-eighteenth century, academic journals began to specialise, especially in medicine. The first journal to be published fully under the peer-review process, „Medical Essays and Obser-

Wiesbaden 1991, pp. 32-64; R. Capurro. Medien (R-) Evolutionen: Platon, Kant und der Cyberspace [online] 2000. [access 10 October 2017]. Available in Internet: http://www. capurro.de/leipzig.htm; M. Landfester, Der Neue Pauly. Enzyklopädie der Antike, Weimar 1999, p. 7; H. Rösch. Wissenschaftliche Kommunikation und Biblio-theken im Wandel. „B.I.T.online” [online] 2004, 2, p. 113-125. [access 10 October 2017]. Available in Internet: https://www.b-i-t-online.de/archiv/2004-02/fach1.htm.

12 „Philosophical Transactions of the The Royal Society Publishing” [online].1665[access 10 October 2017]. Available in Internet: http://rstl.royalsocietypublishing.org/. 
vations", came out in 1731, for instance. However, long, extensive works with broader theoretical considerations soon disappeared from academic magazines and were published in books instead. After the Second World War, modern science developed rapidly. A paper from 2010 estimates the number of all articles published to date at over 50 million $^{13}$. The doubling time is estimated at every eight to 15 years. Therefore, 3.5 million articles are supposedly added every year - and rising ${ }^{14}$.

With the emerging digitisation of texts and contents, a physical medium with digital contents (floppy disks, CD ROM, DVD) initially came into being in a brief transition phase. We have chosen to ignore this phase as it is incapable of yielding any relevant contributions concerning the departure from the linear text. The actual breakthrough of virtuality came with the advent of the internet in 1995. Only through the availability of a global, nigh-on permanently accessible network virtually anywhere did the digitisation of academic communication also experience a paradigm shift. At that stage, text was still merely available as an act of many for the mediation of academic contents and the discussion of the results. And so the new technological possibilities created by computerisation and especially software such as Microsoft Word began to change the way in which texts were written and presented once and for all. Firstly, some academic journals also began offering an electronic version as a supplement to the print issues. For instance, academic publishers started to issue print full texts in PDF form in parallel. Primarily thanks to the arrival of the World Wide Web, however, a completely new level of academic publishing was achieved in the 1990s. Suddenly, the web with its possibilities of compiling (academic) texts in a non-linear form as an HTML file also enabled links and leaps within one or several documents to be incorporated. Consequently, numerous expanded digital forms emerged, including interactive functions that are all rooted in these new technological possibilities. For example, the fact that there is a significant proportion of journals today that are exclusively published as an online version, such as in HTML for-

13 A. Jinha, Article 50 million: an estimate of the number of scholarly articles in existence. „Learned Publishing” 2010, vol. 23, no. 3, pp. 258-263.

${ }_{14}$ P. O. Larsen, M. von Ins, The rate of growth in scientific publication and the decline in coverage provided by science citation index. „Scientometrics” 2010, vol. 84, no. 3, pp. 575-603. 
mat (e.g. „Research Trends”, ISSN 2213-4441 ${ }^{15}$ ), can almost be viewed as a natural evolutionary step. Moreover, Web 2.0 and social media are no longer used solely by private users for communication as an increasing number of academics are also getting excited about these swift and flexible tools. This development is far from over. In fact, a mounting number of alternatives to the linear text that simplify academic communication and render it more interactive and transparent are appearing.

\section{Beyond the linear text}

Specialist papers like those that have been found in classic printed academic journals for centuries are primarily linear texts and fulfil four basic functions of a publication according to Shorley and Jubb ${ }^{16}$ :

- Registration: guaranteeing credit for the author;

- Certification: recognition as a verified academic insight;

- Awareness:communication in the specialist community;

- Archiving:the long-term safeguarding of the work.

Until the advent of digitisation and the internet, these four fundamental tasks had been sufficient. Meanwhile, however, there are numerous influencing factors that radically change the previous system of academic publishing with its solid parameters based on the analogue world. Not only are things published at an increasing rate; the quantity of data produced and analysed for these projects is staggering. Back in 2009, a study by RIN (Research Information Network) detected a strong correlation between the frequency of the use of e-journals and the research output from universities. Furthermore, the younger generation of researchers in particular seeks simpler, faster and more extensive possibilities to exchange ideas and collaborate.

Print publications, by contrast, are static and offer zero interactivity; they cannot be perused in full text without a matching digitised version and are usually readlinearly from beginning to end, even if skimmed. At the same time, the references are inconvenient to read and verify. The

15 „Research Trends” [online]. 2007- [access 10 October 2017]. Available in Internet: https://www.researchtrends.com.

16 D. Shorley, M. Jubb, The Future of Scholarly Communication, London 2013. 
production process for a publication is painstaking (compiling a manuscript using text software, printing, distribution). An academic's research process here cannot be presented adequately and the necessary context of the research project, such as the underlying data, is lacking. An exchange of ideas with other academics becomes more difficult, i.e. comments cannot simply be tagged on, such as for a blog entry. Nor can errors be corrected promptly. According to a 2007 study, 50\% of all specialist papers published are not read by anyone except the authors themselves, the reviewers and the journal's editors. Or to put it less politely, print publications tend to gather dust on the bookshelves.

In recent decades, all these parameters have prompted academics, publishers and other parties within and outside the academic community to start modernising their academic communication. This also includes questions as to how research projects might be presented, formatted, distributed, exchanged and contextualised more effectively.

Meanwhile, there are a large number of possibilities and forms to break away from classic academic publications and their text centricity. For instance, the academic exchange among researchers through usergenerated contents of Web 2.0 and social media is possible via many channels. New electronic forms are available that overcome the lack of flexibility and interaction in linear texts.

The entire process of academic communication, collaboration and publication is subject to these changes. Academics work in an interconnected and interdisciplinary way at different locations in virtual organisations and based on globally distributed resources. Web-based cooperative research and collaboration is summarised under the umbrella term „e-science”.

This begs the question as to whether the classic journal format in print or electronic form is even needed at all these days. In any case, many articles are already published on pre-print servers such as arXiv before their actual publication ${ }^{17}$. Especially in the STM segment, research data containing images, files, correspondence and much more is packed into one, single, large, dynamic object. This collected research data is

17 See $\operatorname{arXiv}$ [online] [access 10 October 2017]. Available in Internet: https://arxiv. org/. It is highly-automated electronic archive and distribution server for research articles. 
subsequently available for further processing or comments from other researchers.

The following examples are alternatives to linear texts, such as extended PDFs, HTML, data journals and social media. They are all used to create and disseminate academic work and can essentially be viewed as successors to the linear text.

\section{New, digital forms of the academic text - Extended PDF documents}

Electronic editions of academic journals and books are currently dominated by the „simple” PDF format. Nonetheless, it merely constitutes an electronic replica of the print publications. Overcoming these limitations of the PDF format, i.e. extending the PDF, is expressed in the Beyond the $\mathrm{PDF}^{18}$ movement, for instance. In recent years, however, numerous extensions with interactive possibilities have been realised.

One interesting example of this special kind of academic text is ReadCube for Researchers ${ }^{19}$, which describes itself as a revolutionary way to read articles (Fig. 1). In the free commercial version, this is a combination of "new” PDF or reader software and a reference management programme such as Mendely or Zotero. It offers functions such as optimised PDF viewing, attachments and related materials, clickable references within the text, complete source lists, figure browser, one-click author search, highlighter tools, full-screen display and a customisable user surface.

Utopia Documents ${ }^{20}$ goes one step further. It is a semantic, academic, web-enabled PDF reader which is part of the Utopia toolbox (Fig. 2). Although Utopia is "only” a PDF reader at heart, it combines the otherwise static PDFs with the dynamic possibilities of the online world in that the PDF documents are rendered in a fully web-enabled way. The PDF file

${ }^{18}$ Beyond the PDF [online] [access 10 October 2017]. Available in Interent: https:// sites.google.com/site/beyondthepdf/.

${ }_{19}$ Readcubes [online] [access 10 October 2017]. Available in Internet: https:// www.readcube.com.

${ }^{20}$ Utopia Documents [online] [access 10 October 2017]. Available in Internet: http:// utopiadocs.com. 
itself is displayed on the left-hand side, the page navigation („pager") in the bottom section of the screen and the side bar on the right with various functions.

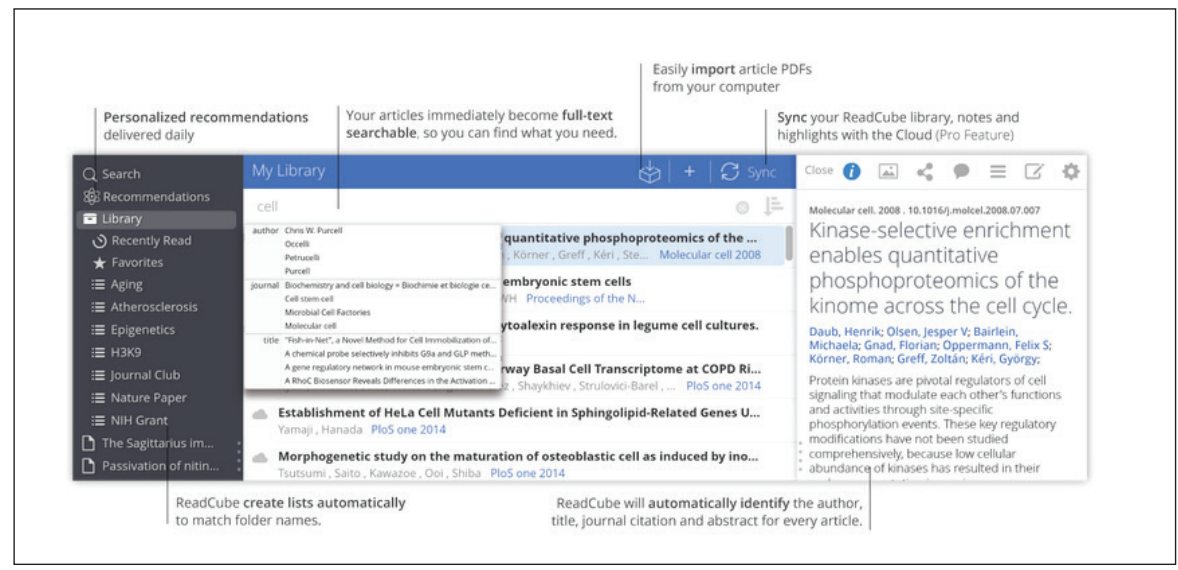

Figure 1. Screenshot of Web service Readcubes.

Source: Readcube [online] [access 10 October 2017]. Available in Internet: https://www.readcube.com/researchers.

With the pager, it is possible to scan back and forth through the documents and move swiftly from one page to the next. The right-hand side bar serves to evaluate the subject matter and discover other content. And naturally it also has interactive possibilities, such as participating in online discussions on an article. Although Utopia Documents can essentially be used to view any PDF file, this application is particularly effective for readers of academic papers from biomedicine and biochemistry. One of the numerous functions also enables the recognition of documents by creating a unique "fingerprint" of its contents and associating it with every version of the articles, even if it is a manuscript version deposited in an institutional repository. Overall, the makers of Utopia Documents have developed a solution that enables static PDF files to be used with all the benefits of modern-day web technology. 


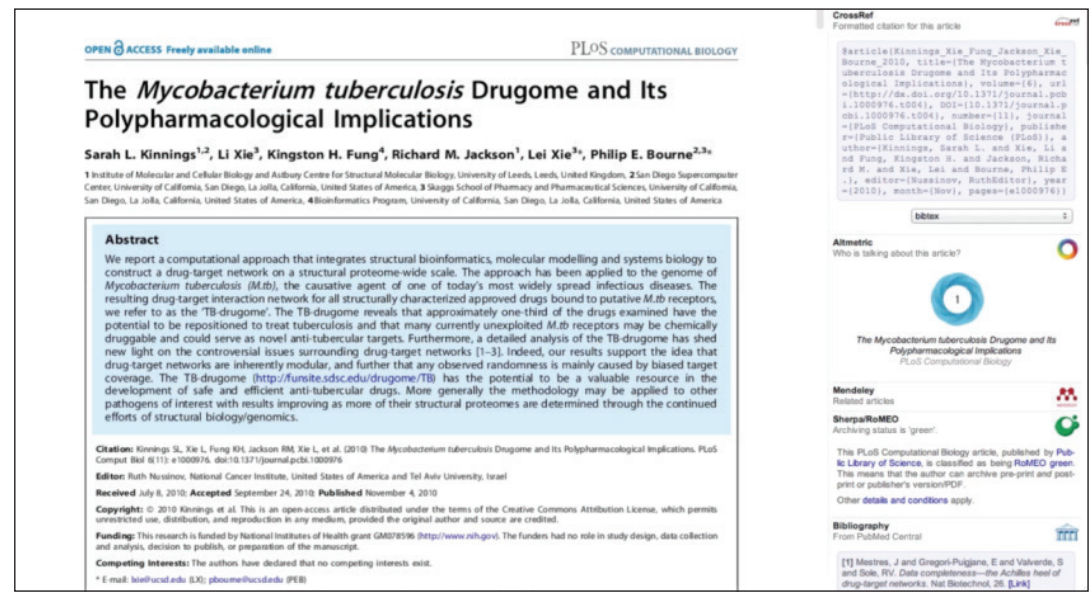

Figure 2. Screenshot of Web service Utopia Documents.

Source: Utopia Documents [online] [access 10 October 2017].

Available in Internet: http://utopiadocs.com.

\section{Extended HTML-based formats}

One example of HTML-based formatsisthe product Article of the Future by Elsevier ${ }^{21}$ (Fig. 3). The Article of the Future format can be described as the starting point for today's modern presentations of specialist papers based on extended HTML formats and their countless functions as are currently standard for the online academic databases of the major publishing houses such as ScienceDirect and Emeraldinsight. This approach was developed to overcome the limitations of linear texts in PDF formats. The key objective is no longer a uniform linear structure (like in a print journal), but rather an integrated, networked navigation system that enables every user to take their own personal route through an academic text. One of the most striking functions of the Article of the Future format is the introduction of (index) tabs that enable readers to switch rapidly be-

${ }^{21}$ I. J. Aalbersberg, et. al., Elsevier's Article of the Future enhancing the user experience and integrating data through applications. „Insights” [online] 2012, vol. 25 (1) [access 10 October 2017]. Available in Internet: https://insights.uksg.org/articles/ 10.1629/2048-7754.25.1.33/. 
tween the summary, full text, method, figures, references, comments and related articles. In doing so, additional interactive elements are constantly supplemented, such as the incorporation of animations, videos, three-dimensional images or downloads of diagrams or tables in various formats.

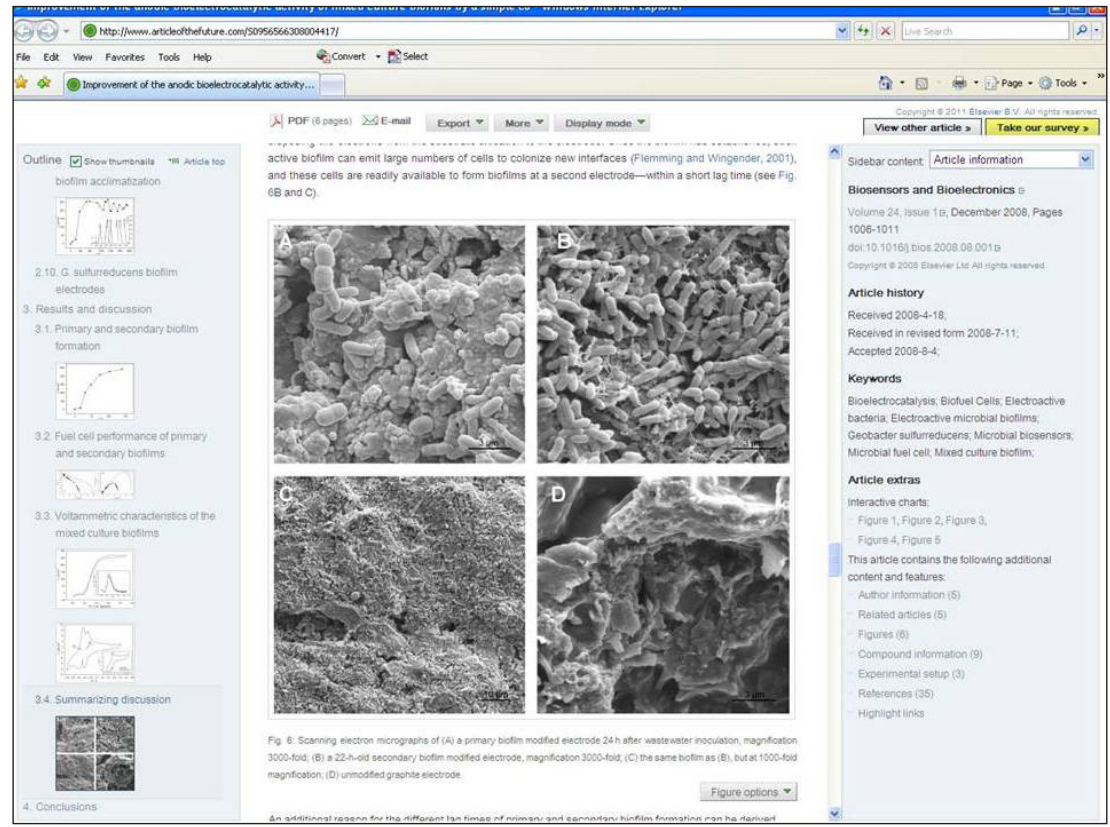

Figure 3. The screenshot of Elsevier's website Article of the Future.

Source: Article of the Future [online] [access 30 June 2018]. Available in Internet: https://web.archive.org/web/20161014053026/http://www. articleofthefuture.com.

\section{Web 2.0 and Social Media - Blogs}

Nowadays, blogs are also one of the popular and most used forms of academic publishing. Visitor statistics and the number of academic blogs like those on ScienceBlogs ${ }^{22}$ have skyrocketed in the last decade (Fig. 4).

22 ScienceBlogs [online] [access 10 October 2017]. Available in Internet: http:// scienceblogs.com/. 
Academics use the blogging option in a variety of ways. Not only are summaries of their projects or articles published on blogs; news or entire papers are also exchanged. A large overview page with diverse blogs by scientists and researchers is available at Researchblogging.org ${ }^{23}$, for instance (Fig. 5).

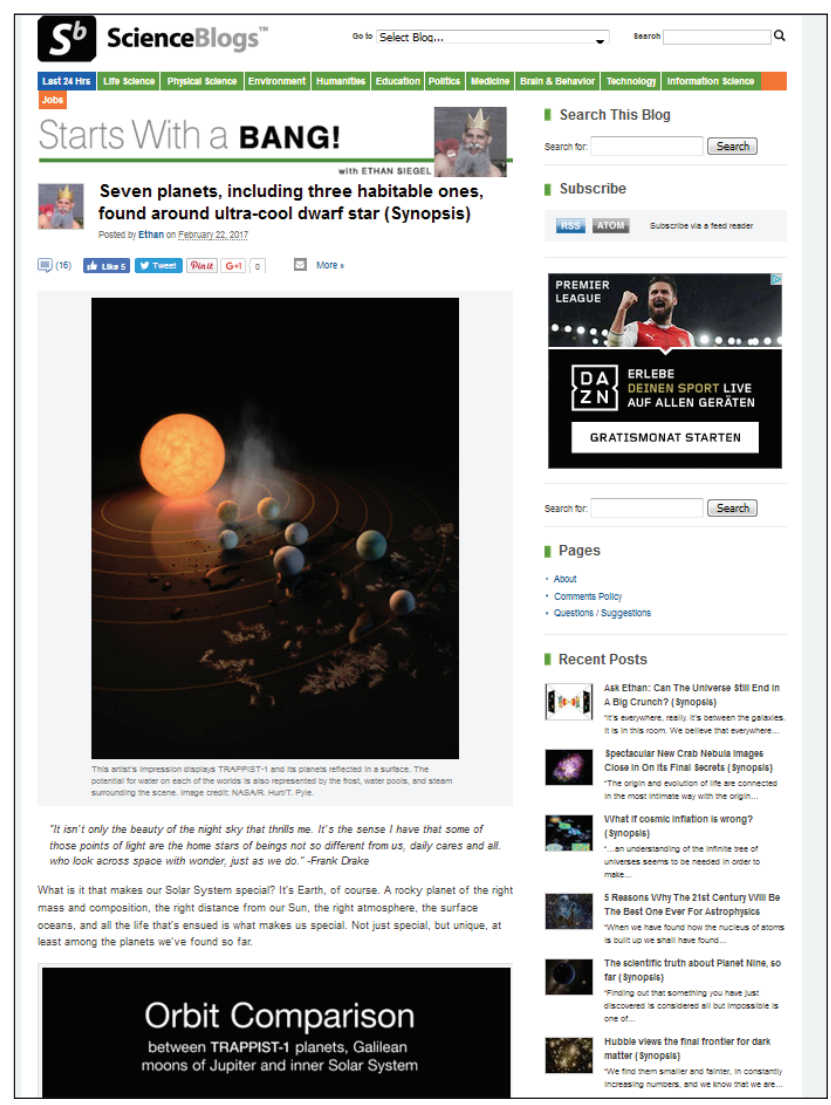

Figure 4. The screenshot of website ScienceBlogs.

Source: ScienceBlogs [online] [access 10 October 2017]. Available in Internet: http://scienceblogs.com.

${ }^{23}$ Researchblogging [online] [access 10 October 2017]. Available in Internet: http:// researchblogging.org/. Current status: In April 2017, the site was adopted by a new caretaker, The Self-Regulation Institute (http://selfregulationinstitute.org/). This caretaker is 


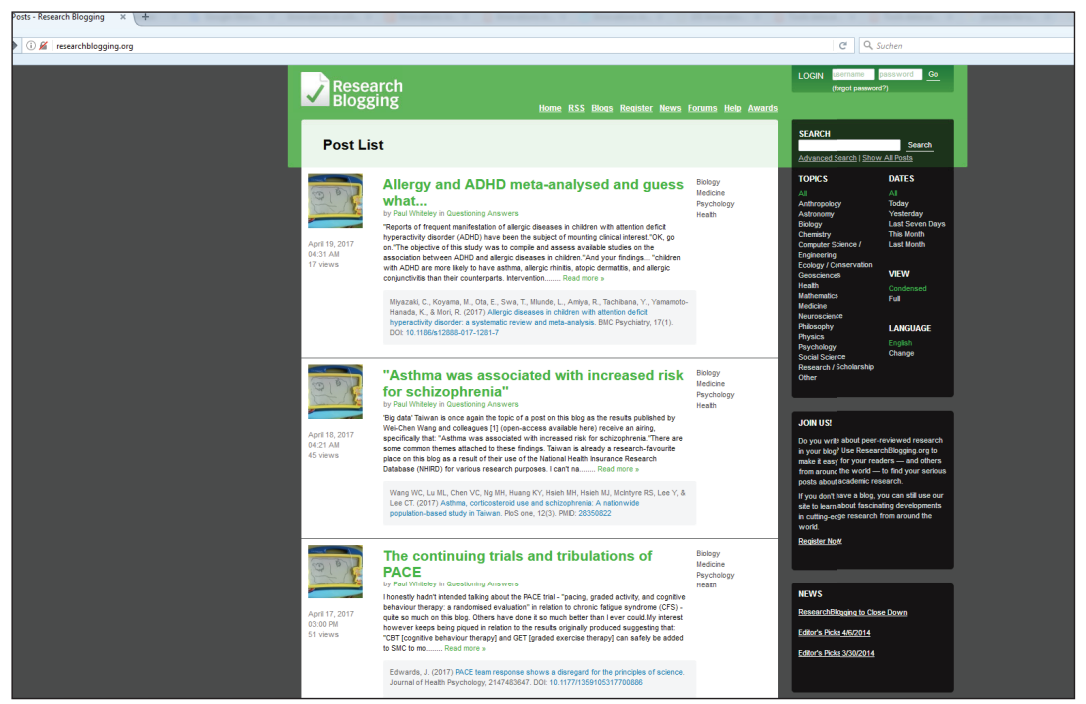

Figure 5. The screenshot of website Researchblogging

Source: Researchblogging [online] [access 10 October 2017].

Available in Internet: http://researchblogging.org.

Frequently, there is also a special blog as a supplement to a journal. One example of this is the Journal of Ecology blog 24 , where additional information on a work published in the journal is provided, including on its background.

Another variation on the blog publication model for academic projects is ScienceOpen ${ }^{25}$. This website is also an aggregator for freely accessible research projects and unites contents from various other research platforms, such as PubMed Central, arXiv or SciELOin one, single place. If articles are displayed in this way, aspects such as the journal brand or impact factor are of lesser importance than the content itself. The users

currently giving the website a complete facelift and background rebuild to ensure it continues to share blogging about peer-reviewed research in valuable and user-friendly ways.

${ }^{24}$ Journal of Ecology: The Blog [online] [access 10 October 2017]. Available in Internet: https://jecologyblog.wordpress.com.

25 Science Open [online] [access 10 October 2017]. Available in Internet: https:// www.scienceopen.com. 
can decide and judge for themselves which papers they read, evaluate in terms of content and would like to share with others. Moreover, Science-Open provides a social network level that enables researchers to communicate with each other and interact with the contents published on this page. It also offers publishers and authors a multifunctional, solution-oriented platform with extended publication possibilities geared towards the latest trends of academic communication. In short, Science-Open is a prime example of the large number of new academic platforms and networks such as ResearchGate or Academia.edu. All these websites use the wealth of opportunities that the internet offers and continuously expand their platforms with new technical possibilities to display, search and distribute academic content.

Compared to classic academic journals - and therefore linear texts blogs have the following advantages ${ }^{26}$ :

- Blogs have open data, codes and materials.

- Blogs use open peer review.

- Blogs do not have a reputation filter as everyone can express their opinion, provided they do not violate the laws of free speech.

- Blogs have better error correction.

- Blogs are open access (and perhaps read more).

\section{Web 2.0 and Social Media - Podcasts}

Podcasts are famouslysubscriber audio and video files that resemble radio or television programmes and can be used via the internet. For example, users can subscribe to a podcast and download new episodes automatically via their smartphone, tablet or computer. In academia, podcasts are often offered as a supplement to an online journal or academic blog. They also provide a new audio-visual way of publishing and presenting academic content. The podcast It's Only Science by the editorial team of „Discover Magazine” is a prime example of their use ${ }^{27}$ (Fig. 6). The two

26 D. Lakens, Five Reasons Why Science Blogs Beat Mainstream Journals. [online]. 19 April 2017 [access 10 October 2017]. Available in Internet: http://principia-scientific. org/five-reasons-science-blogs-beat-mainstream-journals/.

${ }_{27}$ Podcasts. In: Discover [online] [access 10 October 2017]. Available in Internet: http://discovermagazine.com/podcasts. 
most famous academic journals, „Science” and „Nature”, also use podcasts in the same way for academic contentrespectively ${ }^{28,29}$. An overview page with numerous academic podcasts is provided by PlayerFM ${ }^{30}$.

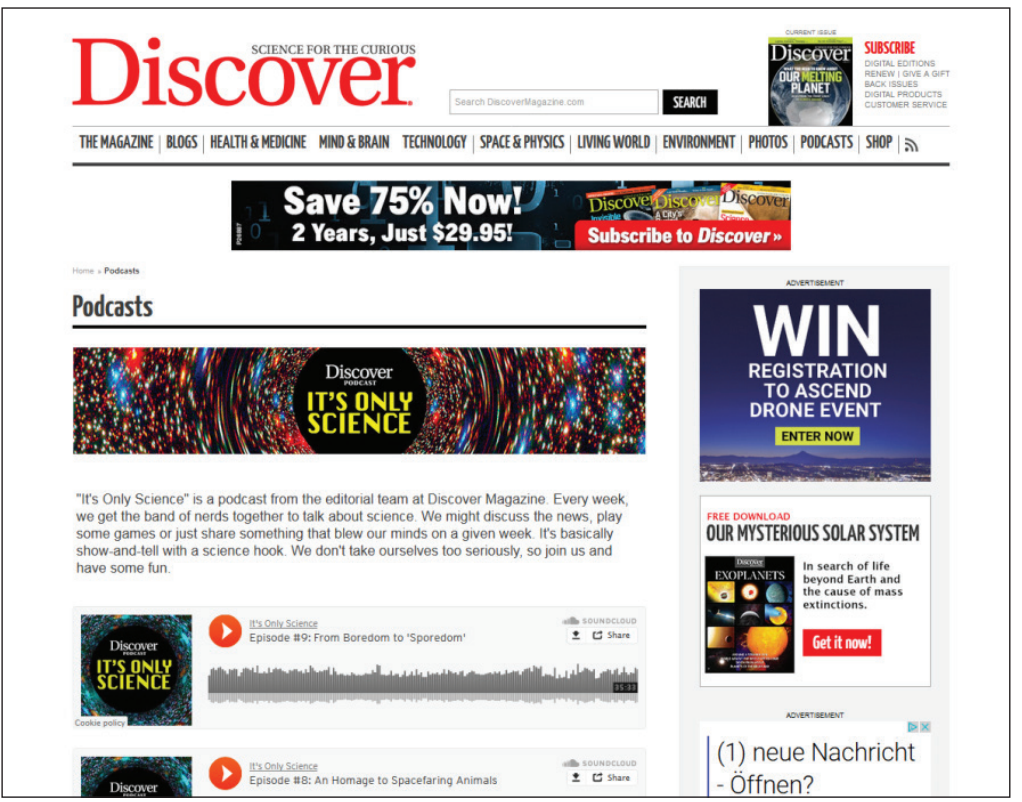

Figure 6. The screenshot of „Discover Magazine” podcast.

Source: Podcasts. In: Discover [online] [access 10 October 2017]. Available in Internet: http://discovermagazine.com/podcasts.

\section{Web 2.0 and Social Media - Short message services: Twitter}

Perhaps the first social platform to draw attention to the potential harboured in sharing academic work online was Twitter. Nowadays, there

${ }^{28}$ Science Podcasts, In: Science [online] [access 10 October 2017]. Available in Internet: http://www.sciencemag.org/podcasts.

${ }^{29}$ Nature Podcasts. In: Nature [online] [access 10 October 2017]. Available in Internet: http://www.nature.com/nature/podcast/index.html.

${ }^{30}$ Science Podcasts. In: PlayerFM [online] [access 10 October 2017]. Available in Internet: https://player.fm/featured/science. 
is hardly an academic conference or congress that can get by without a live Twitter feed. But this short message service is also just the ticket for a rapid exchange of ideas or informing people about new publications. And hardly any academic journals can afford not to have an accompanying Twitter feed these days. The "Journal of Sport Sciences" ${ }^{31}$ is a prime example of its usage, where tables, diagrams or short passages from the full text of the journal's articles are tweeted (Fig. 7). And meanwhile, of course, there are also countless academics who use this channel for their own work or views. Astrophysicist Neil deGrasse Tyson's account is particularly popular at Twitter ${ }^{32}$.

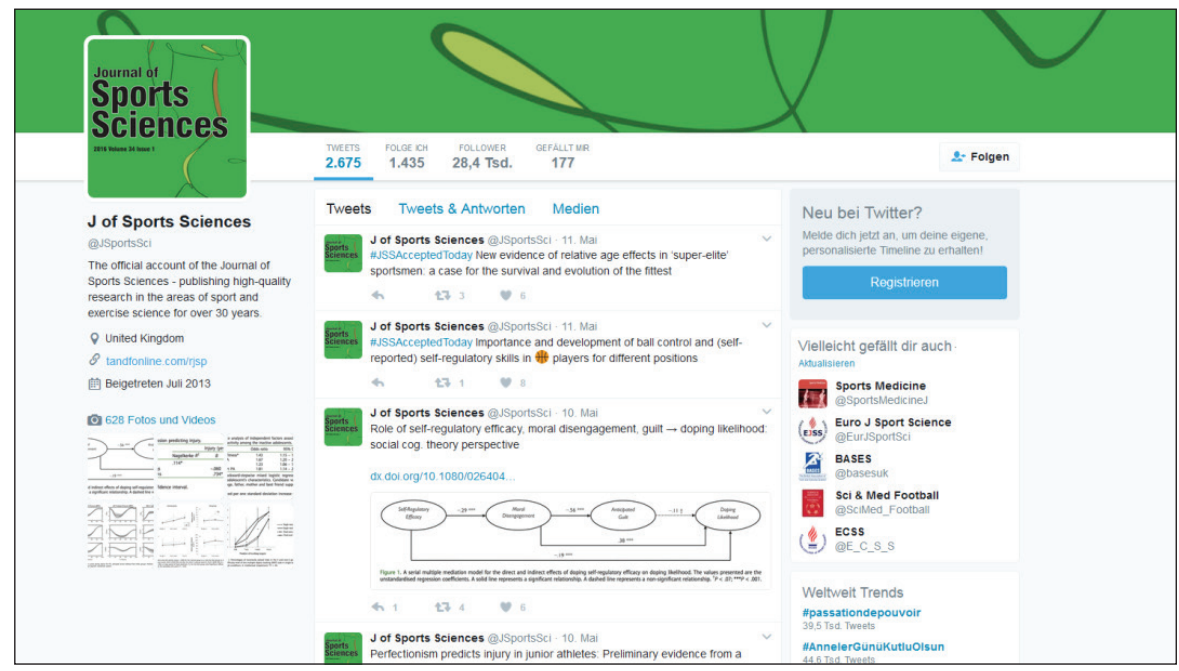

Figure 7. The screenshot of „International Journal of Sport, Exercise \& Training Sciences" on Twitter feed.

Source: International Journal of Sport, Exercise \& Training Sciences. In: Twitter [online] [access 10 October 2017]. Available in Internet: https://twitter.com/ ijsets.

${ }^{31}$ International Journal of Sport, Exercise \& Training Sciences. In: Twitter [online] [access 10 October 2017]. Available in Internet: https://twitter.com/ijsets.

${ }^{32}$ Neil deGrasse Tyson. In: Twitter [online] [access 10 October 2017]. Available in Internet: https://twitter.com/@neiltyson. 
In 2014 was launched „Twournal Of”, the first journal published solely on Twitter $^{33}$. Based on the number of tweets available, however,the journal seems to have never really been active. Nonetheless, it is an application possibility that is worth considering but has not been copied to date.

\section{Web 2.0 and Social Media - Social networks: Facebook, Google+, Instagram etc.}

Nowadays, many academics also use „conventional”, non-academic social networks to connect with their peers or post content. The NASA Instagram page $^{34}$, for instance, displays the best photographs of planets in our solar system or the Universe. Another example worth seeing is the Biodiversity Heritage Library ${ }^{35}$ on the online photo platform Flickr - acompendiumthat contains over 100,000 old academic books dating back to the $15^{\text {th }}$ century. And naturally there are also countless academics and academic journals that use the opportunities offered by Facebook and co. to distribute and share academic content on these networks.

\section{Web 2.0 and Social Media - Videos: YouTube}

YouTube, the video platform operated by Google, offers academics an excellent opportunity to present their work in moving pictures and an extremely visual way. So far, however, the predominantly „academic” use of videos consists in portraying complex academic matters in layman's terms.

One interesting example of the use of YouTube for academic publication is the "Journal of Visualized Experiments" (further: „JoVE") ${ }^{36}$ - an

33 „Twournal of..” [online]. 2014- [access 10 October 2017]. Available in Internet: https://twitter.com/TwournalOf.

${ }^{34}$ NASA. In: Instagram [access 10 October 2017]. Available in Internet: https:// www.instagram.com/nasa/.

35 Biodiversity Heritage Library. In: Flickr [online] [access 10 October 2017]. Available in Internet: https://www.flickr.com/photos/biodivlibrary/sets/.

36 „Journal of Visualized Experiments” [online]. 2006- [access 10 October 2017]. Available in Internet: https://www.jove.com/. 
academic, electronic journal that describes itself as the world's first peer review video journal (Fig. 8). Founded by Moshe Pritsker in 2006, "JoVE" is dedicated to the publication of experiments in a visual format to increase the productivity and replicability of academic research. It is listed in the leading indexing databases such as Pubmed/MEDLINE, Web of Science and Chemical Abstracts and has an impact factor of 1.1. This video journal uses film crews scattered across around 20 countries to document primarily biological, physical and chemical research by visiting the universities and filming the experiments on location. As soon as a shoot is over, the film is released online. This enables scientists in the USA, for instance, to see what their colleagues in Great Britain are currently working on.

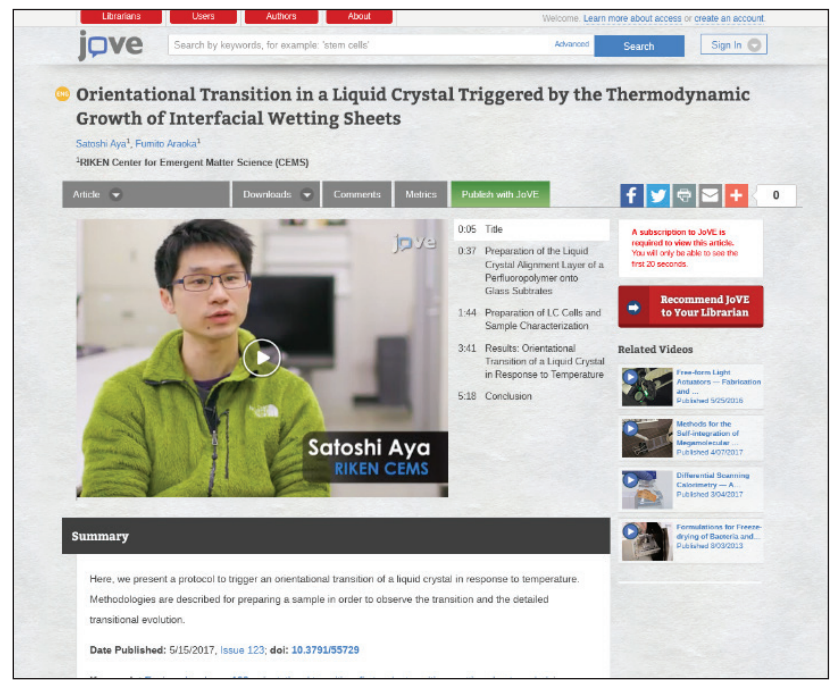

Figure 8. The screenshot of „Journal of Visualized Experiments” website.

Source: „Journal of Visualized Experiments” [online]. 2006- [access 10 October 2017]. Available in Internet: https://www.jove.com/.

\section{Other alternative approaches - Data journals}

Data journals constitute a special kind of academic publishing. The main difference to the classic journal form is the publication of research data, 
i.e. the primary focus of data journals is datasets. The purpose of data journals is to make datasets more transparent and easier to find. These datasets do not necessarily have to be linked to an academic discovery or paper. It is essentially a question of presenting and describing the methods used for this research data in the data papers.

This should enable researchers to discover new things in this data, irrespective of its original interpretation or form of use. Pure data journals are relatively few in number. This special form of academic journal usually exists as a hybrid, i.e. normal, classic academic articles and data papers. Examples of data journals include „Earth System Science Data” ${ }^{37}$, „Biodiversity Data Journal”38 and „CODATA Data Science Journal”39 (Fig. 9).

\section{Other alternative approaches - Living reviews}

Back in 1998 the open access journal „Living Reviews in Relativity" ${ }^{40}$ was initiated. One of the pioneers of the open access movement, it has long since become the first port of call for information on research projects in the field of the theory of relativity. The concept of the "living” article uses the advantages of web-based electronic publishing by enabling authors to incorporate new developments and research results via regular updates. In order to guarantee high academic quality, all the authors are invited by an international editorial committee and the articles are reviewed by experts. The successful concept of living reviews has since been adopted by numerous other publications in a variety of research fields from astronomy to political science.

37 „Earth System Science Data” [online]. 2009- [access 10 October 2017]. Available in Internet: http://www.earth-system-science-data.net/.

38 „Biodiversity Data Journal” [online]. 2013- [access 10 October 2017]. Available in Internet https://bdj.pensoft.net/.

39 „CODATA Data science Journal” [online]. 2002- [access 10 October 2017]. Available in Internet: http://datascience.codata.org/.

40 „Living Reviews in Relativity” [online] 1998- [access 10 October 2017]. Available in Interent: https://link.springer.com/journal/41114. 


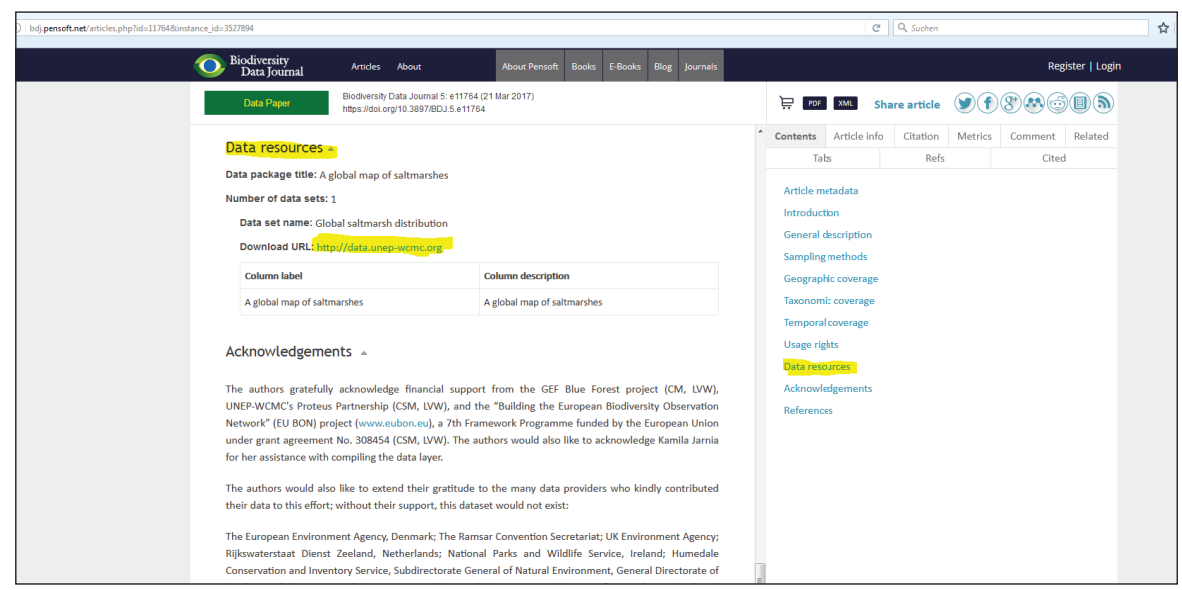

Figure 9. Example of a data resources in „Biodiversity Data Journal”

Source: Ch. J. Mcowen, et. al., A global map of saltmarshes. „Biodiversity Data Journal" [online] 2017, no 5 [accessed 10 October 2017]. Available in Internet https://bdj.pensoft.net/articles.php?id=11764\&instance_id=3527894.

\section{Other alternative approaches - elife's Research Advance augments published articles}

With Research Advance ${ }^{41}$, eLife has introduced a new kind of article that allows authors to add and publish the results of other writers that are based on their own original project (Fig. 10). Thanks to this type of specialist article, authors can explain new developments and consequences for their own work by using up to 1,500 words and up to four diagrams, tables or videos. Research Advance articles are linked to the original papers, yet indexed and cited individually.

${ }^{41}$ Moving research forward: eLive announces the Research Advance In: eLife [online]. 13 August 2014 [access 10 October 2017]. Available in Internet: https://elifesciences.org/ inside-elife/dd67a1b3/moving-research-forward-elife-announces-the-research-advance. 


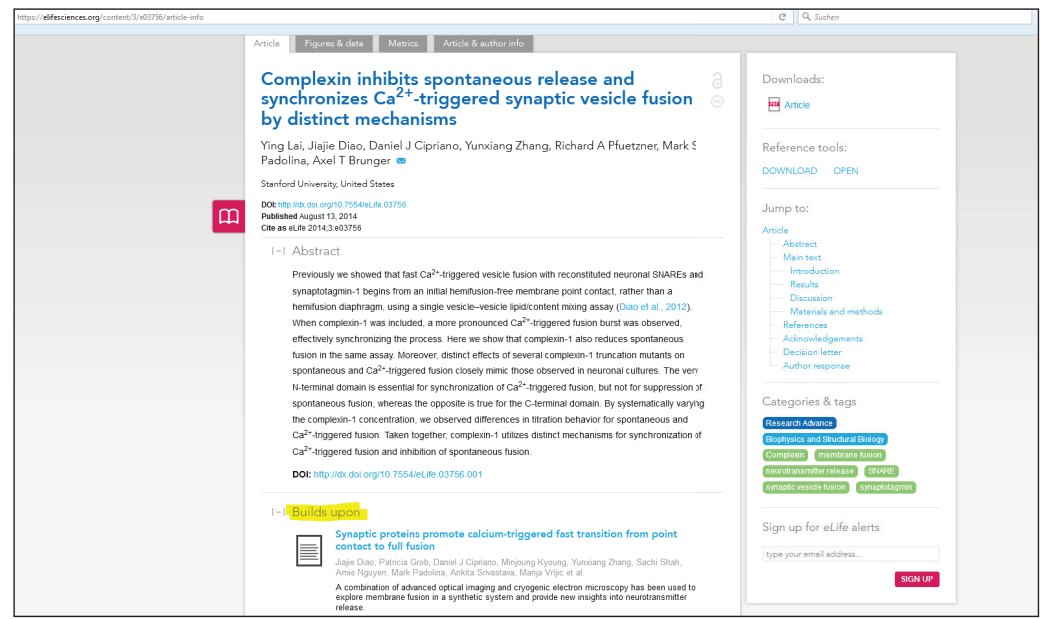

Figure 10. The screenshot of website eLife Research Advance.

Source: Y. Lai, et. al., Complexin inhibits spontaneous release and synchronizes $\mathrm{Ca}^{2+}$ - triggered synaptic vesicle fusion by distinct mechanisms. „eLife” [online] 2014, vol. 3 [access 10 October 2017]. Available in Internet: https://elifesciences.org/articles/03756.

\section{Other alternative approaches - The RG format by Researchgate}

With the RG format ${ }^{42}$, the research network ResearchGate has developed an alternative to the classic PDF file format that exists in various versions for the exchange of academic content (Fig. 11). Although PDFs are widespread and primarily shine thanks to the advantage of looking exactly like a print edition, the main drawback is the static nature of the format. Interactivity to facilitate academic discussions is not directly possible with this old format, which was created by Adobe Systems as early as 1991. Compared to similar portals such as Mendeley and Evernote, which rely on networking via PDFs, the new RG format offers users who publish and read papers on Researchgate the opportunity to interact with both this

${ }^{42}$ Introducing the RG Format. In: ResearchGate [online] 12 February 2015. [access 10 October 2017]. Available in Internet: https://www.researchgate.net/blog/post/ introducing-the-rg-format. 
text and other users. For instance, readers of a publication can highlight and comment on interesting passages. The actual text is displayed on the left-hand side, the interactive column with the discussions on the right. This concept resembles the technology provided by the operators of the website Genius ${ }^{43}$ - previously Rap Genius - for its users. Using a browser plugin - one also exists for the CMS WordPress - users can add comments directly in their browsers in the form of texts, videos, images etc. These line-by-line comments can be used for every page on the web - no longer just for music, but also academic content $\mathrm{t}^{44}$.

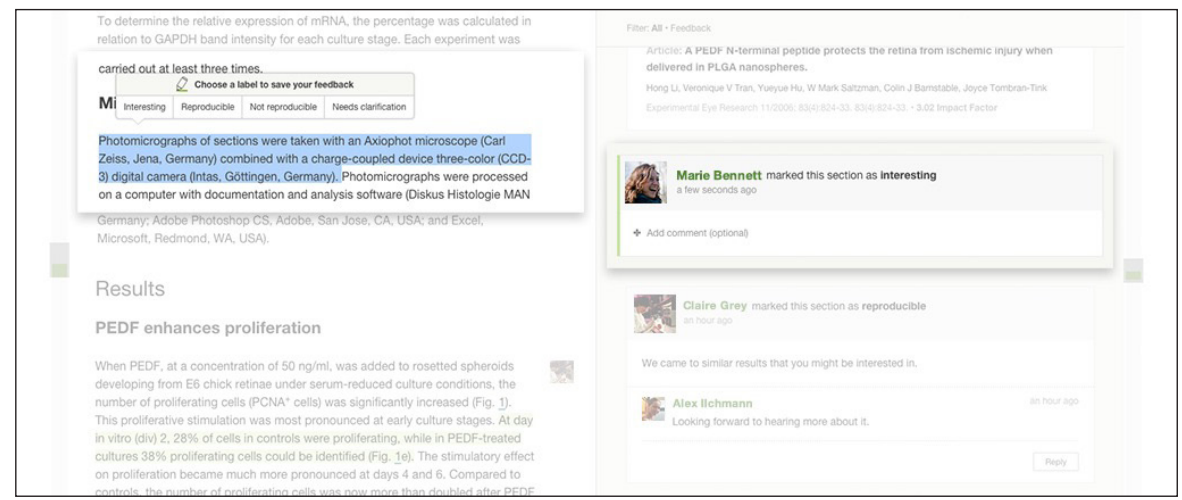

Figure 11. The screenshot of Web service Researchgate.

Source: ResearchGate [online] [access 10 October 2017]. Available in Internet: http://researchgate.net.

\section{Other alternative approaches - textexture.com}

Using the software tool textexture ${ }^{45}$, any text can be visualised as a network (Fig. 12). A text is fed in several times and for every scan certain

${ }^{43}$ Genius [online] [access 10 October 2017]. Available in Internet: http://genius.com.

${ }^{44}$ Web Annotator. In: Genius [online] [access 10 October 2017]. Available in Internet: https://genius.com/web-annotator.

${ }_{45}$ Textexture [online] [access 10 October 2107]. Available in Internet: http://textexture.com/. 
stop words and symbols are removed until every word has been broken down into its smallest unit that conveys meaning (morphemes). These are then used to create and derive connections („nodes”) and relationships. The resulting graph can be used to gain a rapid visual summary of a text, read the most important excerpts (by clicking on the nodes) and find similar texts. This free online software tool was developed by the Berlin-based agency Nodus Labs. The purpose of the application is to offer users the possibility of reading texts in a truly non-linear way thanks to an interactive presentation. Using this visualised network, it is easy to find the most relevant topics in a text, for example. Moreover, it indicates the relationship between these topics, highlights the most influential words in the text and enables the user to switch rapidly to other texts and topics via the corresponding selection ${ }^{46}$.

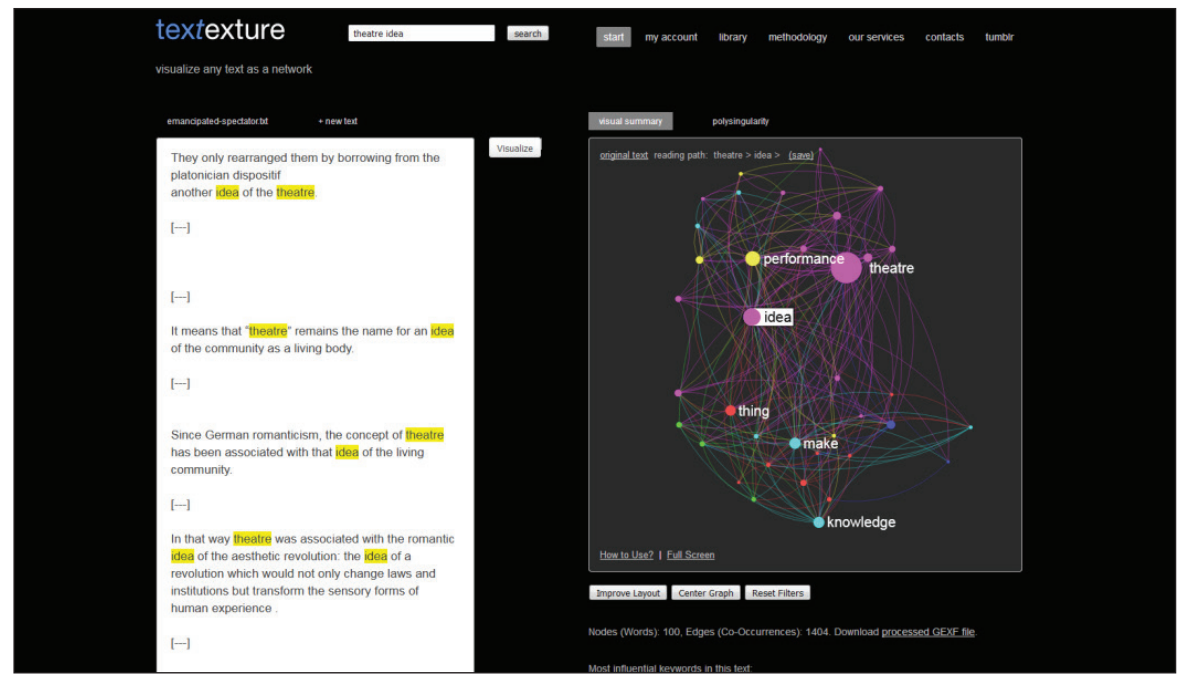

Figure 12. The screenshot of website Textexture.

Source: Textexture [online] [access 10 October 2107].

Available in Internet: http://textexture.com/.

46 Textexture: The Non-Linear Reading Machine. In: Nodus Labs [online] 5 November 2012 [access 10 October 2017]. Available in Internet: http://noduslabs.com/cases/ textexture-non-linear-reading-machine/. 


\section{Summary}

For different (also good) reasons, the majority of academics worldwide still rely on traditional publication forms to exchange knowledge, i.e. print or classic electronic publications, and therefore the linear text. The influence of the internet with its multifaceted, advanced technologies, however, is ever-increasing. This is because it allows many new possibilities that, at least in the long run, will not go unnoticed, such as:

- Navigatingthrough content and reading texts can take place based on one's own ideas and does not have to be linear, which simultaneously encourages the discovery of new information.

- Communicating within an academic community can be simplified, which primarily means a more rapid distribution of academic content.

- The re-use of research data by other researchers and a visually oriented and therefore more realistic portrayal and presentation of academic research content is also facilitated.

- Today's technological possibilities to interact are used and the researchers can report on the progress of their own projects transparently and up-to-the-minute in blogs and on social media. Peers, on the other hand, have the opportunity to immediately comment on and refine these projects and declared progress.

However, there is a whole series of reasons as to why these modern forms of academic communication have not caught on more rapidly or across the board. Many academics, for instance, still harbour reservations regarding these forms of academic exchange. Furthermore, there is often also a lack of the necessary digital competence and the ability to manage data. Fear of "idea theft” by other researchers also seems rife. And the pressure on academics to publish in (classic) journals with a high impact factor is considerable.

Nowadays, however, the academic journal is already merely more "a component" of academic communication ${ }^{47}$, even if the impact factor of a journal is still held in extremely high regard and many researchers tend

47 A. Odlyzko, The future of scientific communication [online]. [access 10 October 2017]. Available in Internet: http://www.dtc.umn.edu/ odlyzko/doc/future.scientific. comm.pdf. 
to keep publishing their results as specialist papers in classic journals, even though they can be distributed and perceived far more effectively through new media formats.

Consequently, additional digital formats with the aforementioned properties may establish themselves alongside the linear text in the long run. The days of the printed article seem numbered, however. Or as Gary Evoniuk, Policy Director at the British pharmaceutical company Glaxo Smith Klein, put it:

The paper journal, and the paper article, will soon be dead. This makes me a little bit sad ${ }^{48}$.

\section{The consequences for libraries}

For several millennia, libraries have been specialists for preparing, processing and archiving texts with a wide variety of content. Until now, nontextual contents have been stored, indexed and documented in museums or archives solely in the form of artworks, photographs and other concrete objects. The processes in libraries are therefore almost completely attuned to, adjusted towards and fixated on textual content. This goes for the acquisition, procurement, indexing, cataloguing, documentation, borrowing, provision and, of course, also the archiving of these entities. After all, there are also hardly any procedures to get around thissuch as the new examples of non-textural formats of academic communication outlined and presented above.Methods and techniques to index and process videos, for instance, (e.g. the Competence Centre for Non-Textual Materials (KNM) at German National Library of Science and Technology (TIB), Hanover ${ }^{49}$ ) are developing only gradually. This also and especially goes for the special form of incomplete documents (fluid PDF), which fundamentally go against the nature of library categories from the com-

${ }^{48}$ M. Taylor, The Future of Scholarly Scientific Communication In: Sauropod Vertebra Picture of the Week [online]. 20 April 2015 [access 10 October 2017]. Available in Internet: https://svpow.com/2015/04/20/live-blog-the-future-of-scholarly-scientific-communication/.

49 Lab Non-textual materials [online] [access 10 October 2017]. Available in Interent: https://www.tib.eu/en/research-development/non-textual-materials/. 
pleteness of the contents accepted and archived in the holdings. However, academia itself does not have any solutions for working with the new forms of its communication, such as the issue of citation or authorship in fluid documents. But answers also need to be found for other open questions, such as the manipulability of online publications.

\section{Bibliography}

Aalbersberg IJsbard Jan, et. al., Elsevier's Article of the Future enhancing the user experience and integrating data through applications. „Insights” [online] 2012, vol. 25 (1) [access 10 October 2017]. Available in Internet: https:// insights.uksg.org/articles/10.1629/2048-7754.25.1.33/.

arXiv [online] [access 10 October 2017]. Available in Internet: https://arxiv.org/. Beyond the PDF [online] [access 10 October 2017]. Available in Interent: https:// sites.google.com/site/beyondthepdf/.

„Biodiversity Data Journal” [online]. 2013- [access 10 October 2017]. Available in Internet https://bdj.pensoft.net/.

Biodiversity Heritage Library. In: Flikr [online] [access 10 October 2017]. Available in Internet: https://www.flickr.com/photos/biodivlibrary/sets/.

Budapest-Vienna Declaration on the European Higher Education Area [online]. 2010 [access 10 October 2017]. Available in Internet: http://www.ehea. info/media.ehea.info/file/2010_Budapest_Vienna/64/0/Budapest-Vienna_ Declaration_598640.pdf.

Cahn Michael, Die Medien des Wissens. Sprache, Schrift und Druck, [in:] Der Druck des Wissens. Geschichte und Medium der wissenschaftichen Publikation, ed. Michael Cahn, Wiesbaden 1991.

Capurro Rafael, Medien (R-) Evolutionen: Platon, Kant und der Cyberspace [online] 2000. [access 10 October 2017]. Available in Internet: http://www. capurro.de/leipzig.htm.

„CODATA Data science Journal” [online]. 2002- [access 10 October 2017]. Available in Internet: http://datascience.codata.org/.

Data Journals. In: Humboldt-Universität zu Berlin [online] [access 10 October 2017]. Available in Internet: https://www.cms.hu-berlin.de/de/dl/dataman/teilen/dokumentation/ datajournal/datajournal.

Open Data Journals In: Foster [online] [access 10 October 2017]. Available in Internet: https://www.fosteropenscience.eu/taxonomy/term/114. 
Genius [online] [access 10 October 2017]. Available in Internet: http://genius. com.

Hitchcock Steve, Carr Leslie. Hall Wendy. A Survey of STM Online Journals 1990-1995: The calm before the Storm. In: The Open Journal Project [online]. 15 January 1996 [access 10 October 2017]. Available in Internet: http:// journals.ecs.soton.ac.uk/survey/survey.html.

International Journal of Sport, Exercise \& Training Sciences. In: Twitter [online] [access 10 October 2017]. Available in Internet: https://twitter.com/ijsets. Introducing the RG Format. In: ResearchGate [online] 12 February 2015. [access 10 October 2017]. Available in Internet: https://www.researchgate.net/ blog/post/introducing-the-rg-format.

Jinha Arif, Article 50 million: an estimate of the number of scholarly articles in existence. „Learned Publishing” [online] 2010, vol. 23, no. 3 [access 10 Ocober 2017]. Avaible in Internet: https://onlinelibrary.wiley.com/doi/ epdf/10.1087/20100308.

„Journal of Advances in Neurosurgery" [online] [access 10 October 2017]. Available in Internet: http://www.vjadvancesinneurosurgery.com/index.php. Journal of Ecology: The Blog [online] [access 10 October 2017]. Available in Internet: https://jecologyblog.wordpress.com.

„Journal of Visualized Experiments” [online]. 2006- [access 10 October 2017]. Available in Internet: https://www.jove.com/.

Lakens Daniel, Five Reasons Why Science Blogs Beat Mainstream Journals. [online]. 19 April 2017 [access 10 October 2017]. Available in Internet: http://principia-scientific.org/five-reasons-science-blogs-beat-mainstream-journals/. Landfester Manfred, Der Neue Pauly. Enzyklopädie der Antike. Weimar 1999, p. 7. Larsen Peder Olesen, von Ins Markus, The rate of growth in scientific publication and the decline in coverage provided by science citation index. „Scientometrics" [online] 2010, vol. 84, no. 3 [access 10 Ocober 2017]. Avaible in Internet: https://www.ncbi.nlm.nih.gov/pmc/articles/PMC2909426/. Lascaux. In: Wikipedia [online] [access 10 October 2017]. Available in Internet: https://en.wikipedia.org/wiki/Lascaux.

Li Ying, Benjamin Simon C., High threshold distributed quantum computing with three-qubit nodes. „New Journal of Physics” [online] 2012, vol. 14 [access 10 October 2017]. Available in Internet: http://iopscience.iop.org/article/ 10.1088/1367-2630/14/9/093008.

„Living Reviews in Relativity” [online] 1998- [access 10 October 2017]. Available in Interent: https://link.springer.com/journal/41114. 
Moving research forward: eLive announces the Research Advance. In: eLife [online]. 13 August 2014 [access 10 October 2017]. Available in Internet: https:// elifesciences.org/inside-elife/dd67a1b3/moving-research-forward-elifeannounces-the-research-advance.

NASA . In: Instagram [access 10 October 2017]. Available in Internet: https:// www.instagram.com/nasa/.

Nature Podcasts. In: Nature [online] [access 10 October 2017]. Available in Internet: http://www.nature.com/nature/podcast/index.html.

Neil deGrasse Tyson. In: Twitter [online] [access 10 October 2017]. Available in Internet: https://twitter.com/@neiltyson.

Nguyen Hai Viet, et al., Preference and willingness to pay for nutritional counseling services in urban Hanoi [version 1; referees: 2 approved, 1 approved with reservations]. „F1000Research” [online] 2017, 6:223 [access 10 October 2017]. Available in Internet: https://f1000research.com/articles/6-223/v1. Odlyzko Andre, The future of scientific communication [online]. [access 10 October 2017]. Available in Internet: http://www.dtc.umn.edu/ odlyzko/doc/ future.scientific.comm.pdf.

„Philosophical Transactions of the The Royal Society Publishing” [online]. 1665[access 10 October 2017]. Available in Internet: http://rstl.royalsocietypublishing.org/.

Podcasts. In: Discover [online] [access 10 October 2017]. Available in Internet: http://discovermagazine.com/podcasts.

Readcubes [online] [access 10 October 2017]. Available in Internet: https:// www.readcube.com.

„Research Trends” [online]. 2007- [access 10 October 2017]. Available in Internet: https://www.researchtrends.com.

Researchblogging [online] [access 10 October 2017]. Available in Internet: http:// researchblogging.org/.

Rösch Hermann, Wissenschaftliche Kommunikation und Biblio-theken im Wandel. „B.I.T.online” [online] 2004, 2, p. 113-125. [access 10 October 2017]. Available in Internet: https://www.b-i-t-online.de/archiv/2004-02/fach1.htm.

Science Open [online] [access 10 October 2017]. Available in Internet: https:// www.scienceopen.com.

Science Podcasts. In: PlayerFM [online] [access 10 October 2017]. Available in Internet: https://player.fm/featured/science.

Science Podcasts, In: Science [online] [access 10 October 2017]. Available in Internet: http://www.sciencemag.org/podcasts. 
ScienceBlogs [online] [access 10 October 2017]. Available in Internet: http:// scienceblogs.com/.

Shorley Deborah, Jubb Michael, The Future of Scholarly Communication, London 2013.

Spicer Scott, Exploring Video Abstracts in Science Journals: An Overview and Case Study. "Journal of Librarianship and Scholarly Communication” [online]. 2014, 2 (2) [access 10 October 2017]. Available in Internet: http://jlsc-pub. org/articles/abstract/10.7710/2162-3309.1110/.

Szlezák. Reading Plato, London, New York 1999, pp. 56-71.

Taylor Mike, The Future of Scholarly Scientific Communication In: Sauropod Vertebra Picture of the Week [online]. 20 April 2015 [access 10 October 2017]. Available in Internet: https://svpow.com/2015/04/20/live-blogthe-future-of-scholarly-scientific-communication/.

Textexture [online] [access 10 October 2107]. Available in Internet: http:// textexture.com/.

Textexture: The Non-Linear Reading Machine. In: Nodus Labs [online] 5 November 2012 [access 10 October 2017]. Available in Internet: http://noduslabs. com/cases/textexture-non-linear-reading-machine/.

„Twournal of..” [online]. 2014- [access 10 October 2017]. Available in Internet: https://twitter.com/TwournalOf.

Utopia Documents [online] [access 10 October 2017]. Available in Internet: http://utopiadocs.com.

„Earth System Science Data” [online]. 2009- [access 10 October 2017]. Available in Internet: http://www.earth-system-science-data.net/.

Video abstrats. In: Elseviers [online] [access 10 October 2017]. Available in Internet: https://www.journals.elsevier.com/journal-of-number-theory/ video-abstracts.

Lab Non-textual materials [online] [access 10 October 2017]. Available in Interent: https://www.tib.eu/en/research-development/non-textual-materials/.

Web Annotator. In: Genius [online] [access 10 October 2017]. Available in Internet: https://genius.com/web-annotator.

\section{Odchodzenie od linearności tekstu}

STRESZCZENIE: Od tysiącleci, od czasu pojawienia się pisma, przekazywanie pełnej wiedzy było ograniczone do pisemnego przekazywania informacji za pomocą 
tekstu linearnego. Komunikacja akademicka wykorzystuje przede wszystkim tekst linearny, nawet w kwestiach matematycznych i związanych z naukami ścisłymi. Przez około 20 lat postępująca cyfryzacja środowisk akademickich umożliwiła wizualizację złożonych kontekstów i ich propagowanie na ogromną skalę, bez ograniczenia tekstem linearnym. Eksternalizacja wiedzy i jej transfer od jednej osoby do drugiej może teraz odbywać się również za pomocą alternatywnych technik. Jest to równoznaczne z rewolucją w komunikacji akademickiej. Stanowi to ogromne wyzwanie szczególnie dla bibliotek, ponieważ przez ostatnie 2000 lat były one nastawione na przechowywanie i rozpowszechnianie zasobów akademickich niemal wyłącznie w formie tekstowej.

SŁOWA KLUCzowE: komunikacja naukowa, tekst, nielinearność, cyfryzacja, wizualizacja, przekazywanie wiedzy, cyfrowy tekst 